\title{
Women in Balinese Topeng: Voices, Reflections, and Interactions
}

\author{
Margaret Coldiron, Carmencita Palermo, \\ and Tiffany Strawson
}

This article charts the increasing involvement of women performers in Balinese topeng (mask dance) and emerged from discussions and emails among the authors. Following an overview explaining women's traditional absence from this form and noting the pioneering women who have been at the forefront of change, the authors discuss how, as non-Balinese female performers and researchers, they discovered that they shared many similar stories, curiosities, and challenges relating to their training and experiences. Their insights provide a detailed picture of some important issues for women in Asian theatre.

Margaret Coldiron is a London-based theatre director, performer, teacher, and specialist in masks. She performs Balinese music and dance with Gamelan Lila Cita and Lila Bhawa Indonesian Dance Company and is the associate director of Thiasos, a theatre company specializing in intercultural productions of ancient Greek plays. Her publications include Trance and Transformation of the Masked Actor in Japanese Noh and Balinese Dance Drama (2004) and articles and reviews in Asian Theatre Journal, New Theatre Quarterly, Indonesia and the Malay World, and Women and Performance. She is currently the deputy head of the BA in World Performance Program at East 15 Acting School, University of Essex.

Born in Sicily, trained in Bali, and currently based in Tasmania (Australia), Carmencita Palermo is a researcher, writer, and performer who focuses on Indonesian masked dance performance and mask embodiment cross-culturally. Her performance and teaching practices explore the dynamics of interaction between body, masks, music, audience, and environment in different cultural contexts, with particular attention to the roles and perspectives of women. She has performed and taught in Australia, Indonesia, Europe, and Brazil. She is currently a postdoctoral researcher at the University of Naples.

Tiffany Strawson is a performing artist, researcher, and dramaturg who makes performances in site- and culture-specific contexts. She is undertaking doctoral research on the embodiment of Balinese topeng mask in a posttraditional, women-centered, and intercultural context-exploring notions of presence, translation, and the relationship between movement and ritual. In 2007 she initiated the Bali Unmasked project, which 
promotes intercultural exchange by supporting Balinese performers to teach and perform in the United Kingdom. She also mentors UK students' studies in Bali. Her academic publications include contributions to theatre, dance, performance, and training.

At the Women in Asian Theatre conference held at the University of Lincoln in September 2013, a panel focused on women performers of the Balinese masked dance-drama topeng (the word topeng refers to both the genre and to the mask object). Evidence indicates that the form has been in existence since at least the ninth or tenth century BCE (Bandem and de Boer 1995: 45; Goris 1954, 1; 55; 2: 121); it is performed in ritual contexts as a complete dance-drama by up to five dancers using a variety of masks, or, in the context of a secular concert or a tourist performance, a single mask may be performed as a solo character study. The stories for the dramas are derived from the babad, legendary chronicles of Balinese kings. Topeng is traditionally performed by men, and nearly all of the characters depicted in topeng masks are male, but in recent years a few women have ventured into the genre, challenging convention.

There has been some excellent recent scholarship examining the emergence and development of women's roles in a variety of Balinese performing arts, in particular Catherine Diamond's wide-ranging (2008) examination of women in traditional and nontraditional performance, Emiko Susilo's dissertation on women's gamelan (2003), Jennifer Goodlander's recent Asian Theatre Journal article on female dalangs (2012), and Carmencita Palermo's study of women in Balinese topeng (2009). These works chart the enthusiasm as well as the inhibitions and frustrations for these female "pioneers." The preponderance of males in Balinese performing arts has been regarded as "traditional," but (as has been evidenced in many other cultures) tradition often develops out of habit or need rather than by any divine plan (the divine plan is usually invented subsequently to justify the tradition). Women historically have not been topeng performers because they had no time either to train or to perform. Their domestic and ritual duties (including preparation of daily and ceremonial offerings) took up all of their energies (Palermo 2009). Dances in the temple and, later, in hotel and tourist shows are generally performed by young girls and boys, while mature married women usually perform only the processional ritual mendet to welcome or bid farewell to the gods at a temple ceremony. However, when Western women began to come to Bali to study some of the traditionally male arts in the 1970s and showed real skill, the notion of women in these male roles began to seem less outlandish. ${ }^{1}$ The advent of the performing arts academy ${ }^{2}$ (which trains both young men and young women in traditional arts) along with increased 
wealth, modern labor-saving devices, and the New Order directives about gender equality have all given women context and opportunity to enter into these formerly male-dominated fields (Diamond 2008; Goodlander 2012: 54-60).

Since the 1970s an increasing number of foreign students, both male and female, have traveled to Bali to study traditional music and dance-drama. Some of the early trailblazers wrote books and articles about their experiences, and many have become important scholars and teachers of Balinese culture in the universities of Europe and the United States. Where they led, many more have followed. Two women in particular have served as agents of change. Rucina Ballinger traveled to Bali in the early 1970 s to study music and dance, and in the course of this studied topeng with I Nyoman Kakul of Batuan. Kakul also taught many other foreign students, including John Emigh, Ron Jenkins, and Deborah Dunn, all of whom went on to write about their experiences with topeng. Ballinger stayed in Bali, married a prince from Mengwi, and has since become an insider/outsider critic and prominent commentator on Balinese arts. She is also one of the only women to have performed in the spiritually powerful mask of the widow-witch Rangda, traditionally performed only by men because of their perceived superior "strength." 3

In the 1980s Cristina Formaggia, an Italian who had studied kathakali in India, arrived in Bali and felt she had found her artistic home. She studied topeng and gambuh (classical court dance-drama) with I Made Djimat in Batuan and became an accomplished performer. Although a foreigner, she was gradually accepted by the Balinese and performed regularly in temple festivals alongside some of the most esteemed local artists for more than twenty years until her death in 2008. She was highly respected for her skill and discipline and for her work in preserving and recording the ancient court art of gambuh. In collaboration with Ni Desak Nyoman Suarti ${ }^{4}$ she also established an all-female topeng group called Topeng Shakti in 1997-1998, ${ }^{5}$ which had among its members some of the most important and respected female performers from Bali. They performed at the Bali Arts Festival in 2000, at the Magdalena Festival in Denmark in 2001, and at Festival De L'Imaginaire at the Maison Cultures Du Monde in Paris in 2003.

Another agent for change has been travel outward, not only for international tours of Balinese performing groups, but also with Balinese performers traveling to Australia, the United States, and Europe to study. Performers such as I Made Bandem, I Wayan Dibia, I Nyoman Sedana, and I Nyoman Catra have contributed to international understanding of Balinese arts and returned to Bali to become influential teachers. This cross-cultural exchange is now a 
constant in Balinese arts, so much so that students from the West and elsewhere in Asia regularly travel to Bali, while Balinese artists, including those mentioned above, are invited to be artists-in-residence at universities or with performing groups in Australia, Europe, Asia, and the United States.

Carmencita Palermo, Tiffany Strawson, and Margaret ("Jiggs") Coldiron are all scholars, teachers, and performers of Balinese topeng who trained with master teachers in traditional village settings in Bali. The three came together for the 2012 conference of the International Institute of Asian Studies titled "Bali in Global Asia: Between Modernisation and Heritage Foundation" at Udayana University in Denpasar, Bali, and began a discussion and collaboration that culminated in a panel at the Women in Asian Theatre Conference in Lincoln. Palermo is originally from Sicily and, after living in Indonesia on and off for ten years, is now based in Tasmania. Strawson, from the United Kingdom, also has developed her knowledge of Balinese masks by traveling between Europe and Bali, funding her passion by freelance teaching and directing theatre projects. Coldiron is an American who trained as an actress and has lived in London for many years, working primarily as a teacher and director in professional actor training programs. From very different backgrounds, they are united in their passion for topeng. In preparation for the conference they embarked on a three-way discussion about how and why they, as Western women, came to be so fascinated by this foreign and traditionally male genre and how they see their own position within the world of Balinese topeng, both as women and as foreigners (see Fig. 1). The discussion is set out in the form of an extended interview with some additional interpolations from the papers presented at the conference. The aim was to find whether there were commonalities in their experience of this traditionally male form and whether, through an examination of their own experience with topeng, they could develop any theories about why Balinese female performers who have the skills and experience to perform the genre generally do not do so.

\section{Q: Why did you decide to study topeng?}

CARMENCITA PALERMO: I first watched a topeng performance in Italy when a troupe performed as part of the International School of Theatre Anthropology/Odin Theatre in 1990. That time the Italian mask performer Pino Confessa was part of the troupe led by I Made Bandem. Then I watched it again in Bergamo a couple of years later. This time Cristina Formaggia was performing with I Made Djimat. For some reason Italians were always involved. I felt a strong attraction, and as a performing arts student I believed I 


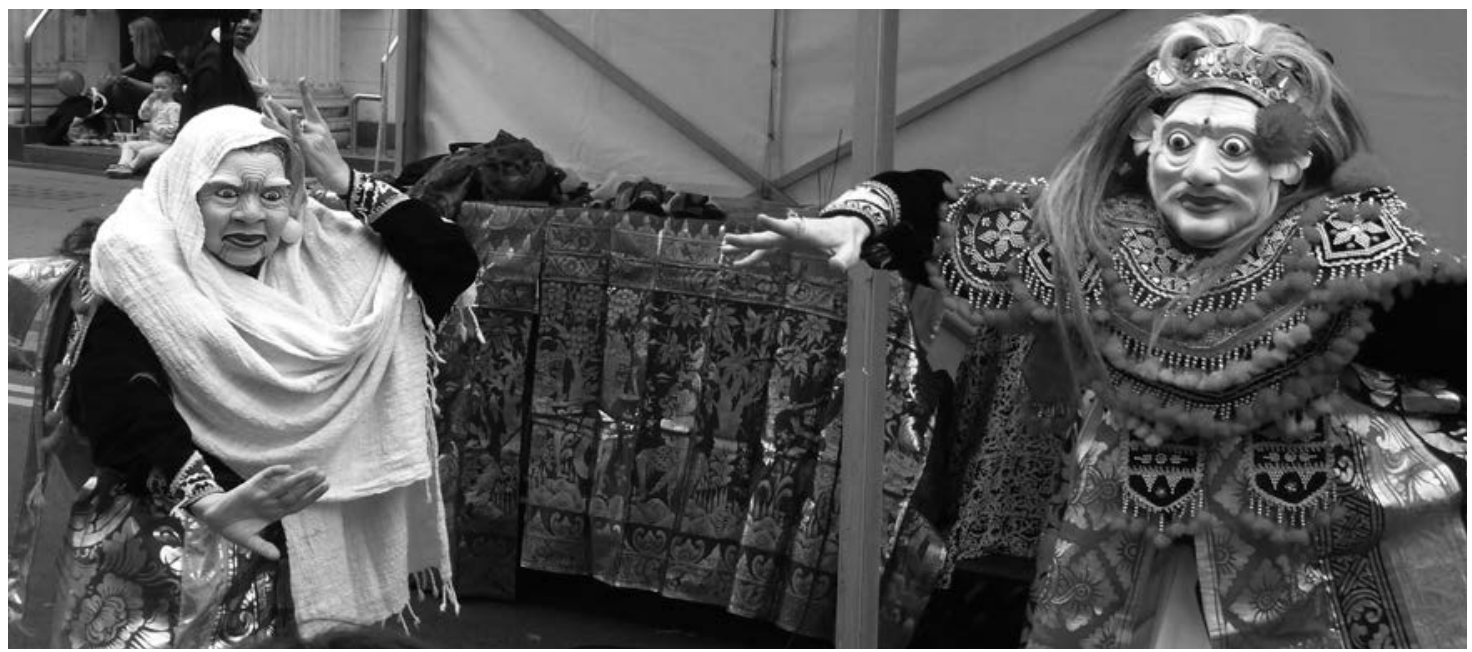

Figure 1. M. J. Coldiron (Jiggs) and Carmencita Palermo in masks of the Topeng Tua (Old Man) and Topeng Tua Wanita (Old Woman) at the Surbiton Festival, September 2012. (Photo: Joe Fraser)

was seeing a living form of commedia dell'arte, a living and necessary performance and not a reinvention of tradition. This strong feeling stayed dormant for a long while. When I went to Bali to do research on $k e c a k^{6}$ for my master's degree in 1994, I didn't even dare to think I could learn to dance. I Wayan Dibia suggested that I live in the village of Bona to carry out my research, where I Made Sija and his family lived. Sija is a significant figure in Balinese traditional arts, known primarily as a dalang (puppetmaster), topeng performer, and specialist in making offerings. At the time he was one of the people responsible for the local kecak group that performed daily for tourists, and his whole family were involved. I followed the family to rehearsals for the kecak competition at the Bali Arts Festival, but also I followed the group when they performed wayang kulit shadow puppets or topeng. I was absorbing in silence everything I Made Sija was doing, including making masks, but I did not dare to even try to ask to learn. I was so fascinated by his ability to change character through a piece of "lifeless" wood on his face, but I did not dare to imagine that I could do the same. However, in the last month of my studies something shifted. I made a mask with topeng master Ida Bagus Oka from Mas, and then with Ida Bagus Alit from Lodtunduh. Ida Bagus Alit insisted I learn a dance, so I had a couple of lessons but didn't have the time to do more. That unfinished business made me feel that I must return 
to Bali. I won't forget the moment when I Made Bandem told me about the Darmasiswa program [a scholarship offered by the Indonesian government for foreigners to study Indonesian language and arts in Indonesia]. As soon as I landed in Italy I made my application at the Indonesian embassy. I wanted to go back to Bali and learn topeng, and soon after I returned to study for two and a half years.

TIFFANY STRAwSON: Topeng, as opposed to other mask traditions in Bali, was a fusion of dance and drama and seemed to me to be more akin to familiar European forms like commedia dell'arte. Moreover, topeng did not involve trance and so seemed more accessible. I imagined I would go to Bali for two months, enjoy the experience of seeing another culture and traveling, and I would learn a new set of skills to add to my theatrical toolbox. I supposed that I would "get it out of my system." Little did I realize that my first trip would ignite a love affair that would last until now! I imagined that I wanted to learn about performance and theatre, but it was actually the culture, the ritual, and the spiritual significance of the mask that had the greatest impact on me. It gave the performance an overwhelming sense of completion and purpose that was completely new to me. After my first visit, I decided to study topeng with more dedication and saved up to return. I sold everything to get back as soon as possible. My second visit to Bali was also intended to be two months, but I stayed a year and a half because I felt as if nothing else was more important. My family and friends were upset and confused, wondering what on earth I was doing out there. I felt as if I were making very clear, difficult choices that would influence my life. Although I wasn't making very great progress on that visit, I didn't understand much of what was happening around me (I was culturally confused most of the time and always seemed to be making mistakes), I felt a compelling sense of belonging to the masks and the performance.

MARGARET COLDIRON: I went to Bali for the first time in 1991, where I saw a tourist performance of topeng Tua [the Old Man mask-a character study of an elderly statesman, once a vigorous warrior, but now beset by old age], and I was utterly entranced. I was teaching neutral and half masks in the Copeau/St. Denis style at the Drama Centre London at the time. I loved masks and I was thinking of doing a masters' degree, so I thought I could make topeng my subject. However, when I began to find out more about the form and realized it would be impossible to learn more in London, except from books; I decided to make it my PhD study, along with the masks of Japanese $n \bar{o}$ drama. 


\section{Q: Was it the masks that interested you first? If not, what?}

PALERMO: Absolutely yes, it was the masks and the challenge of making alive something "dead"- that was my challenge.

STRAWSON: It was definitely the masks. I was disillusioned with the mask scene in the UK, as there is a symbiotic relationship between underfunding and lack of popularity for mask work. At the time mask work seemed to be associated mostly with children's theatre. I wanted to go somewhere where the mask tradition was alive, vibrant, and part of popular performance. Initially I was not interested in learning the performance aspect myself; as a "craftswoman" I just wanted to learn how to carve. Only after eight years or so was I encouraged to dance, to bring "life" into the design. Since I have started to gain a better understanding of the masks, the context of ritual space, spiritual worship, sounding mantra, and all of the qualities that fuse to make a performance have become entangled. As with any level of specialism, the more one learns, the more there is to be learned.

COLDIRON: I've always been fascinated with masks and how they work, and I'm still discovering more all the time. Like Carmencita, I was astonished by the way these masks came alive in performance and seemed to have such a strong sense of "attention" and focus. Perhaps it's because the features are so strong, perhaps because the eyes are very prominent and have a very clear gaze that one feels their power when they look at something. Even just hanging on a wall or animated by a hand they are full of life.

Q: Which mask is your favorite? Did your favorite change when you learned the dances?

PALERMO: When I started I loved all strong and funny characters! I was good at those, and the Balinese were very encouraging because I could be so funny and my feet were "like a man"-so it was easy for me. It was me! My first regular teacher was I Nyoman Cerita, whom I met when I was attending the STSI in Denpasar; I also studied with I Gusti Suweka and I Ketut Suteja, who taught topeng and baris [warrior dance]. ${ }^{7}$ Soon I started taking daily lessons from I Ketut Kantor in Batuan while I was regularly visiting and following I Made Sija and Ida Bagus Alit and seeing their performances. The fact that I was officially enrolled at STSI gave me a certain amount of freedom to follow several different teachers. ${ }^{8}$ They all gave me the opportunity to perform, and since strong, funny characters are so free and flexible, nobody would really question who my teacher was. After a couple of years I realized I had to "step up" to greater challenges, and my journey sent me in search of the refined characters. The 
technical precision of I Nyoman Cerita helped me explore topeng Monyer Manis, a refined comic character created in Denpasar in the 1950s. My daily lessons with I Ketut Kantor and the long conversations I had with I Made Sija helped me slowly be able to explore the masks of topeng Tua and Dalem, the refined king.

STRAWSON: I do not have a "favorite," but I do feel a very much stronger connection to the mask topeng Keras Gajah Mada [prime minister of the kingdom of Majapahit, ca. 1290-1364], a mask designed by my teacher Ida Bagus Alit from Lodtunduh. This is partly because this was the mask that he assigned me to because of my body type, and I am actually, in a sense, "married" to this mask, having done a pasupati ${ }^{9}$ ceremony. Ironically, I have since realized that most of Alit's students start off learning topeng Keras, ${ }^{10}$ mainly because it is his favorite. Although I cannot claim to feel spiritually in tune with this mask, or even fully confident in my ability to bring it to life, I am fascinated by the multiple obstacles and challenges this mask presents to me both culturally and as a woman. I find the more refined characters such as Dalem (the refined king) easier, but I cannot claim that that one is my "favorite." I love dancing all of them as part of a sequence, each having their own particular nuance, character, and choreography. I enjoy finding in my body the fluctuation between kerasmeaning strong and powerful—with halus, meaning soft, sweet, and refined. I also enjoy the intercultural potential of these principles of energy and, as a result of my explorations, I carved a variety of what might be termed "posttraditional masks." I was interested to see what would happen if I changed the strong male mask of topeng Keras to a female to reflect the twenty-first century in which the president could be a woman-for example, Megawati Sukarnoputri of Indonesia [president 2001-2006]. I therefore imagined a new mask in collaboration with Ida Bagus Alit and renamed her Ibu Berani, which translates as "Mrs. Brave" or even "Mother Courage." Ibu Berani indicates that she is a warrior, a fighter, but it was also a nickname of my own, so I felt a deeper investment in this design from the outset. I found that these qualities and associations gave me a connection to the mask before I had even started to envisage how I would carve the wood and how it would speak to me. In Bali, bravery for a woman is mixed up with all kinds of culturally specific associations and not necessarily viewed positively, as Unni Wikan (1990) describes. In this mask, although the red color and strong features that are characteristic of topeng Keras are somewhat toned down, they are still present. It has a strong masculine energy of kerasness, but because it is a new mask that I created, when I began to explore it physically my choreography changed and "bridged" my 
instinctive movement with the strong movement world of topeng Keras Gajah Mada so that I found in positions of stillness my positions were naturally lower and breathing was easier.

COLDIRON: Topeng Tua was my favorite mask and that was how I began, but, like Tiffany and Carmencita, I really started by learning to make masks; I was not brave enough to start with dancing. I felt it would be "inappropriate" or even "offensive" since I was both a foreigner and a woman, so I began by learning to carve with Anak Agung Gedé Ngurah, a mask carver and community leader who lives next door to Ida Bagus Alit. Then one day Alit came by as I was carving and told me that it was no use trying to learn to carve if I didn't know the dances, so that's when I started to learn to dance. It was difficult. Although I'd studied various kinds of dance over the years (tap, ballet, jazz, contemporary, and flamenco), I'd never approached anything like Balinese dance and I was starting very late-already forty. Perhaps topeng Tua was a good place to start! It was awfully difficult. I didn't really understand the music, and learning in traditional village style meant simply copying the teacherno explanations or analysis. I had spent fifteen years teaching character analysis and Stanislavsky acting technique, so it took a long time to be able to read things directly into the body without any kind of "intellectual" barrier that would question everything. Now, after many more years of study and practice in topeng, I have learned a great deal and it is much easier-I have also progressed. I still love topeng Tua, but I now identify strongly with topeng Keras and find it fascinating to explore his various iterations. I have identified at least ten variations in this mask and I own three versions of topeng Keras-one that is somewhat refined, the Gajah Mada designed by Ida Bagus Alit (to which Tiffany refers), and one that is rather demonic that I have decided is Patih Pasung Grigis. ${ }^{11}$ They are all very different in their challenges. I also have topeng Lucu (a comic mask with pursed lips) and Topeng Bues, ${ }^{12}$ which I really love-he's a bullying, aggressive coward, a kind of comic thug. I have also worked on Dalem (prince), which, when I began, was the character I did best (at least according to the village children who regularly invaded my lessons). However, this mask is a big challenge because it is very technically demanding, requiring exquisite refinement along with a great subtle power that must be carefully contained. It has been a journey, and the journey continues.

\section{$\mathrm{Q}$ : What is the feeling you have when wearing the mask?}

PALERMO: The moment in which I feel totally one with the mask is what I aim for, and it does truly happen, but only when I manage to be 
one with the music and with the audience-that's a truly blessed moment!

STRAWSON: Wearing a mask, in my experience, is the most extreme example of performance; somehow the feeling of "performance" is heightened-the adrenalin, the joy, and the purpose. So when I am wearing the mask, it's hot and sweaty and becomes uncomfortable as the dance goes on, but I forget all that because it is one time when I feel really present and in the moment and responsive. I feel vibrant and fully in the body as I embody the mask. One of the few common elements in the discourse on mask characterization in the literature and in my discussions with performers was that in order for the mask to be alive the performer had to be "one with the mask," menunggal or mesikang or kawin, being married with the mask. ${ }^{13}$

COLDIRON: The feeling of the performer while wearing the mask was the subject of my doctoral thesis-but I don't really feel I have any kind of definitive answer (see Coldiron 2004). It seems to me a matter of desa-kala-patra, a traditional formulation in Balinese culture generally translated as place, time, and circumstance (Gold 2005: 6; Herbst 1998: 1-4). ${ }^{14}$ It sometimes amazes me when I am performing how little I am feeling "in character" and how aware I am of all the other stuff, like "Where's my headdress?" and "Have I done that bit of choreography yet?" Nonetheless, people will say afterward how incredibly convincing the performance was, how expressive the mask was, and how amazed they were that there was a woman underneath. Sometimes I can just put on the mask and go, and it is like a kind of waking dream-that is, if one is really inside the music and the character. The face and the spirit of the mask character are important but, as I have gradually discovered, you really have to be kawin dengan musik ("married with the music"), and I am very grateful that I started playing gamelan, which has given me a much more visceral understanding of topeng. In European dance traditions I feel that we tend to separate choreography from music somehow. Of course great dancers have a special sensitivity to music, but choreography is so often about steps and counts and getting it "right" that it took me a long time to realize that the "feeling" of the character and the choreography is in the music. When one performs with live gamelan the "choreography" is improvised based on a basic movement vocabulary and, as the dancer, you have to drive and inspire the musicians to give the appropriate accompaniment. It is a symbiotic relationship, and wonderful when it really works well. So, what is key for me now is listening to the music over and over until it is in my bones. Balinese people get this for noth- 
ing because they've had these tunes in their consciousness all their lives, but for us, I think, it takes time.

Q: Is performing in the speaking masks like Penasar [the servant/ translator who serves as chief storyteller and engine of the plot in topeng] or bondres [the comic village characters who interact with the Penasar to reveal the story ${ }^{15}$ ] different from the nonspeaking masks?

PALERmo: Penasar? That is not for me yet and is my biggest challenge. My teachers have tried to teach me the songs and the use of the voice. I Ketut Kodi made a younger version-smaller and lighter color-of the Penasar mask to suit my voice. All my Balinese teachers tried to teach me in the same way, asking me to imitate in traditional fashion and to try to reproduce it as closely as possible. Both male and female teachers had the same approach, and I am very grateful for their efforts because I learned a lot about teaching from the Balinese point of view, but I do not wear the Penasar mask. I perform bondres at performances, and when I tell my stories, because I'm more a dancer than an actor, my bondres are absolutely crazy and physically extreme. This is because there is not an actual traditional training dictating the rhythm. I follow the breath of bondres and what the masks dictate in the performative context. I do notice that with bondres things can be completely out of control, and their energy depends a lot on the interaction with the audience and other performers on stage. The full masks have a more established pattern, even those that do not follow a traditional Balinese choreography.

STRAWSON: Speaking masks are different for many reasons-for a start, the relationship to the gamelan changes and the music is softer. This means that the energy is less charged, as it has to make room for dialogue. Also with clowning in a Balinese mask I slip into general, more universal techniques, so for me bondres or Penasar do not feel very much different from any other (Western) character that plays a specific role or function.

COLDIRON: Penasar is a huge challenge, especially vocally. In spite of having been a stage actress and having a fairly low voice, it is not easy to produce the power and consistency required. I did some lessons in tembang (Balinese singing) with I Wayan Dibia, ${ }^{16}$ which I would like to do again on a more regular basis, just so that I could do it with the ease and aplomb that the Balinese men have. I've seen the female topeng groups Topeng Shakti and Luh Luwih, and I think that people like Ni Nyoman Candri ${ }^{17}$ and the others are just as strong as the men. When I saw a women's arja (a dance-drama form sometimes called "Balinese opera") at the Bali Arts Festival 
in 2012, I didn't even realize at first that the Penasar was a woman! Performing Penasar in front of a Western audience is perhaps a little more difficult than for a Balinese audience, because one has to communicate a lot about the genre within the context of the performance, in character. It is a very big job to hold the story together, especially if you are performing some of the bondres masks as wellyou have to remember everything that has gone before, whether or not one was on the stage.

Q: Topeng is traditionally performed by men, and most of the masks are male. Have you learned or were you attracted to women's dances? If not, why not? If you have learned women's dances, what have you done? How is it different from topeng?

PALERMO: I learned the basics of everything that wasn't too pretty. I spent two and a half years at STSI and had to do something there, but never mastered any of them and didn't really want to, except "Rejang Dewa," a bit of "Panyembrama," and I loved "Teruna Jaya."18 I did much better with baris, the warrior dance. Baris is considered the basis of the topeng dance style and fundamental to build up the right muscles and learn basic technique. Dancing without a mask is totally different-different body position, different breath, and distribution of energy. The mask requires a more precise control of the movements through very defined use of breath that, as one of my teachers used to say, "pushes the life out of the mask." Some performers refer to this process as "yoga" since it involves the careful distribution of energy through the body/mind.

STRAWSON: I have learned legong, but I found it too stereotypically "girly" and boring. I am not a dancer, and dance doesn't come naturally to me. I see dance as a particular vocabulary for a language that I don't really speak, but which is necessary to communicate the specific character of each mask.

COLDIRON: I don't perform female dances. It's partly vanity-I had seen English friends doing Javanese dance, and I knew I didn't want my white body on display doing Indonesian dance. I was forty when I started anyway and didn't feel that my body/persona was appropriate for female dances-and they are very difficult! In topeng I feel totally covered, therefore totally transformed. In topeng it's not me on display but the mask, and inside this body-mask I can lead the gamelan and create the character. Another advantage is that topeng is essentially improvisatory, whereas the female dances are strictly choreographed. Once one knows the vocabulary for a given character, one is not stuck with the choreography. Since topeng is generally a solo affair I feel safe knowing that if I make a mistake 


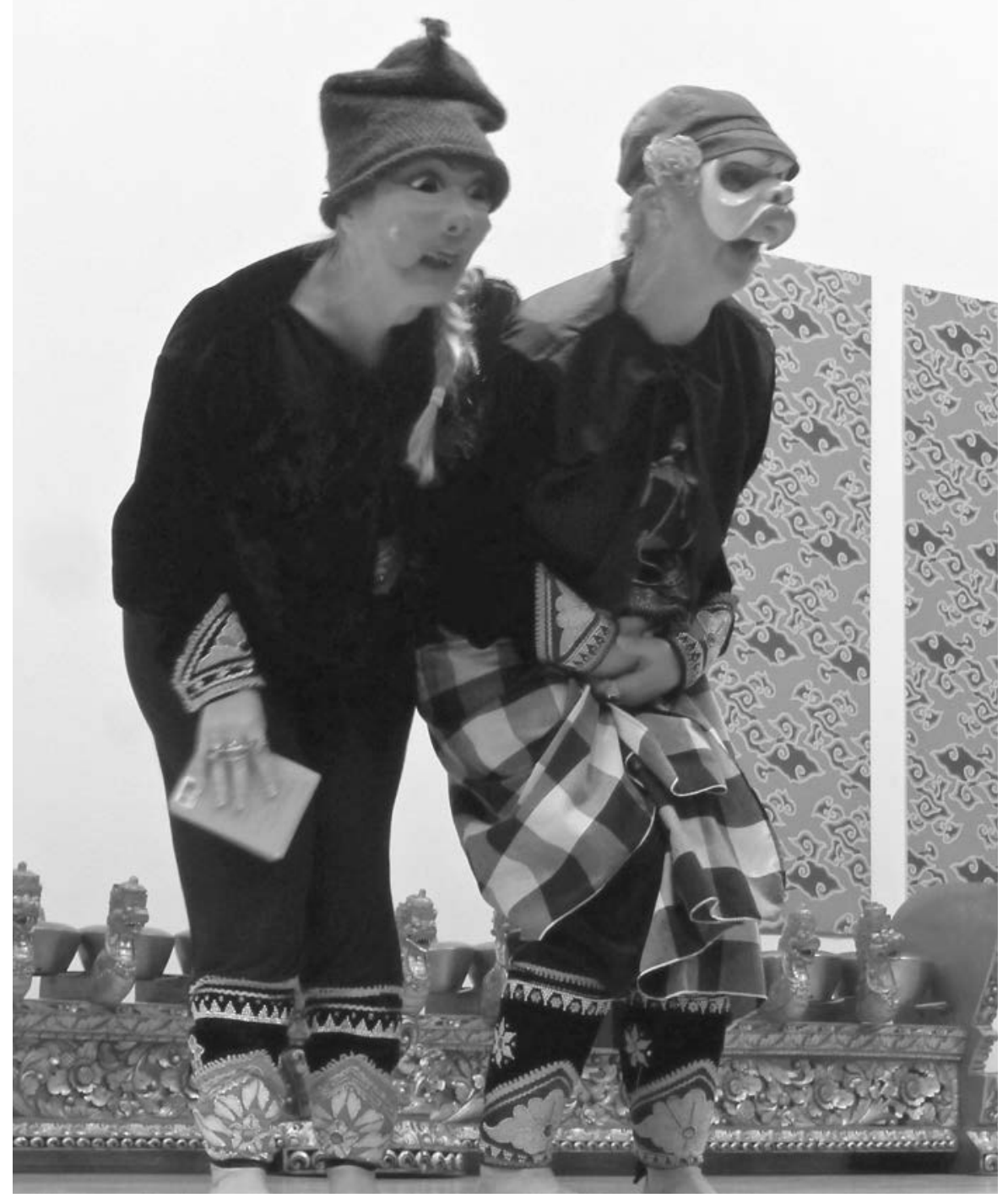

Figure 2. Tiffany Strawson and M. J. Coldiron in bondres (clown) masks in Little Red Riding Hood at the Indonesia Kontemporer festival, School of Oriental and African Studies, London, October 2013. (Photo: Mayang Irsan)

I can capitalize on it and not worry that I'll mess anyone else up. However, I feel that it would be helpful for me to learn female style, because I teach and should be able to better demonstrate the contrast between male and female modes. To this end I have taken one or two lessons in female style dances and I sometimes prac- 
tice with Lila Bhawa Dance Troupe. However, I prefer the male or bebancihan dances and would love to learn "Teruna Jaya"-though perhaps in another life. Nonetheless, I have gained a real appreciation for female dances through playing the gamelan for performances. There may be something in this about one's physical build and having a relatively large, robust frame in an environment (in Bali) where all the people seem very petite, graceful, and beautifully formed. There is no question but that as a Western woman one can feel big and awkward trying to form one's body to female dances, especially in the company of Balinese dancers. There may also be an element of assertiveness and directness in the personalities of women who choose to do topeng that is more appropriate to that genre than the more apparently "submissive" female dances.

\section{Q: How difficult, then, has it been learning topeng?}

PALERMO: Learning is a long journey without end. I absorbed from the first day I entered I Made Sija's house-sitting for hours waiting for him, mingling with women preparing offerings, watching so many performances, listening to so much music. Then I tried with my own body, learning with children, learning at STSI, learning in a one-to-one relationship with my teachers. It means trying to embody principles you think you understand, and coping with the feeling that you'll never get it. Then all of a sudden you feel you've got something. Then, when you see Balinese students who are not really as good as they should be, then you realize that maybe there is hope, at least at the physical level, that you can be better. Then you have the music and the vocal training to take on. To keep up with the training with psychophysical knowledge is the challenge. Wearing someone's face, as I Ketut Kodi described wearing the mask, is a challenge without end.

STRAWSON: It's extremely difficult. In addition to the challenges that the actual dance presents, there are lifestyle and social factors that include 5:30 a.m. starts (when performing at ceremonies). Also, most teachers carry a reputation, which, as a student, you adopt or unconsciously uphold. In particular, certain teachers are known to fraternize inappropriately with female students, and, regardless of one's professional attitude, many people assume that if you are following your teacher you are sleeping with your teacher, and this can be problematic if you live in Bali long term. It takes an added strength of character to rise above this.

COLDIRON: I've been at it now since 1997, so that's nearly seventeen years, and I would say the first ten years were the hardest. It is very hard not being in Bali regularly, and if Ni Made Pujawati [artistic 
director of Lila Bhawa, founded in 2002] had not come to London and begun teaching, I would probably have given up. I'm very glad I've been able to continue because, of course, the more you do the more you learn. Having regular opportunities to perform has also been a huge help. The most important element, for me, has been learning the music-learning to play and understand the gamelan. In the beginning, when I was learning with Alit accompanied by a cassette, he would shout at me to "Listen to the gong!" Well, on his tiny old cassette player I couldn't distinguish the gong at all and I knew nothing of the construction of Balinese music, so I had no idea what to listen for. When I started playing gamelan in 1999 I was determined to learn like the Balinese and refused to use notation to help me out-I just learned by copying and listening. When, gradually, you come to an understanding of how the music works and are able to listen for all the components, rather than just the "tune," the dance makes a lot more sense. Likewise with dancing - the character and the music have to be inside your body. Now, finally, I know where the gong is and when I have to give the signals to the drummers, but learning how the music and the dance work together has been the most important lesson for me.

\section{Q: Do you teach or perform with masks outside Bali?}

PALERMO: When in Bali I have mostly performed traditional Balinese topeng for ceremonies and festivals. Outside Bali, in Australia, Indonesia, Europe, and South America, I mainly perform my own work and teach mask characterization as a whole and don't focus exclusively on Balinese tradition. This happens because, while I'm consciously an ambassador for Indonesian culture, I also want to make it clear that my approach is cross-cultural. The female professional Balinese performers I have interviewed throughout the years demonstrate that their experience is nearly the opposite. For example, Ni Made Wiratini, a well-known arja performer and teacher (and wife of I Wayan Dibia), has performed traditional topeng overseas to support her husband, but she would not perform in Bali. Why? Among other reasons, she would not want to risk losing face by exposing herself to a knowledgeable (and highly critical) audience in Bali. Another example is Ni Made Pujawati, a Balinese dancer based in the UK who never performed a traditional topeng in Bali. The multitalented Pujawati only discovered the pleasure of performing topeng working with Margaret Coldiron in London. Encouraged by I Wayan Dibia, Ni Made Pujawati has now acquired a set of female masks to produce a solo topeng performance, but since she is focused on performing with her London pupils she hasn't had 
the time to work on this new production. The only all-female traditional group that has performed both in Bali and overseas (as far as I know) is Topeng Shakti, which has been inactive since their leader, Cristina Formaggia, passed away in 2008. One of its members, Ni Nyoman Candri, is pursuing her dream of using her father's masks by performing with male performers from time to time for ceremonies. She also has once performed the sacred topeng Sidha Karya, which is fundamental to complete the ceremony. Rucina Ballinger, who was part of the original Topeng Shakti group, went on to found a comedy group made up of foreign middle-aged women, Grup Gedebong Goyang, but they do very contemporary sketch shows and don't use masks. The other two all-female topeng groups from Keramas that were active around 2003-2004 performed a few times for ceremonies and at the Bali Arts Festival, but then time and conditions did not support their activities in the community, and they never performed overseas. Currently there are no all-women topeng groups in Bali, but there are women who perform with masks. Ni Ketut Arini is over seventy years old, an "icon" of Balinese dance and keeps experimenting with the use of the mask. Bulan Jelantink, another prominent figure [a qualified medical doctor and active performer in a range of media], tours Indonesia and overseas with her mask-dance creations. The successful and sustainable examples of Balinese women performing with masks seem to be outside the topeng tradition. In Bali there is not the real change in attitude regarding topeng that has occurred in gamelan music. Now one sees so many women and girls playing gamelan gong kebyar and performing gender wayang, but this revolution has been the result of a long process that started with the first music teachers going to the United States. The work at Çudamani in Pengosekan during the last seventeen years has meant that people now regard it as "normal" to see women playing gamelan in Bali in ceremonies. I am not sure if we'll ever see the day when it will be more "normal" to see a Balinese woman perform topeng in a Balinese ritual context than a female foreigner. For some reason foreign women are still more able to be accepted-perhaps because we are always learners and do not really cross any boundaries.

STRAWSON: On the rare occasions that I have performed with a gamelan here in the UK, I am not convinced that the dance travels so well. These are sacred dances and the intention and context in which they are performed are culturally specific. Nobody in the UK appreciates that this is a male dance, and that the masks are part of a series that tell a story, so it becomes viewed in isolation, and my concern is that it becomes "exotica" and a bit meaningless—a kind 
of exhibit. Of course, in Bali keen attention is paid to technique, particularly in the dancing community, but also there is an understanding that the intention of trying to do one's best as an offering to the gods is also important. Naturally that context does not exist when performing for a Western audience. I love teaching with the masks though. They are always so popular and are loved even though people don't know their meaning. They are so universal because they are archetypes.

COLDIRON: I teach all sorts of mask work, and one of the things that has helped me learn how to do topeng has been teaching it to others. I do some workshops with the comic bondres masks in a way that is similar to the way that I teach other character half-masks, so it is all free improvisation. I am lucky in that I am able to perform on a fairly regular basis in London with Gamelan Lila Cita, and for Indonesian tourism events. Although topeng functions as a sacred and semisacred performance in Bali, I found that Balinese performers regarded every performance as a "gig" - whether for a temple ceremony or a tourist event. There isn't a great deal of difference in approach to the task since in each circumstance there is a careful balance between showing off and reverence. On three occasions I've given topeng "residencies" lasting up to a week, and on two of those occasions I worked with Ni Made Pujawati teaching topeng to participants (sometimes professional actors and dancers, sometimes students) and then giving a full public performance. That was wonderful, challenging, and fun, and I'd like to do more.

Interestingly, although Ni Made studied all of the topeng repertoire in her time at STSI, her first performance in Balinese topeng was in the UK, when Ida Bagus Alit and his nephews came to perform at Dartington and in Cardiff in 2007. I know that she felt rather daunted at the prospect of performing with these established male (and high-caste) performers, but it was a great success for performers and audience alike. I think this helped give Ni Made Pujawati (and myself) courage to promote ourselves as people who could present a traditional topeng performance. She never performed topeng in Bali because her real calling and love was to perform the Condong (lady-in-waiting to the princess) in arja, but in the UK this is not really possible. She is, essentially, a singer and comedian, and these skills are great for topeng. During the time she lived in Bali (until 2000) the idea of women-Balinese women-performing topeng was still virtually unheard of, and she felt she could never be as good as the great male performers. In Europe, however, the field is wide open. 


\section{Q: What kind of performance do you do and why?}

PALERMO: My main production, Women's Breath, is made up of several female masked characters that interact with live musicians. These are usually musicians who join me in the place where I perform. The rehearsal time is usually only around two hours, and during this brief time we learn one another's vocabulary, and that allows us to be in an improvisational dialogue during the performance. Depending on the training of the musicians, they may also interact physically with me in the performance. With this approach I keep an important element of the traditional Balinese topeng, which is interaction with the music based on a real dialogue between performer and musician. The performer decides when to call for a slower or faster tempo or a louder or softer sound, but he or she can do this only at a specific point in the cycle of the music by communicating with the drummer. Because I change the musicians that I work with, the relatively simple structure of my performance changes every time I perform. In Australia, interacting with a didgeridoo or a Tasmanian leather instrument gives different results from those that come from interacting with capoeira musicians in Brazil, for example. I aim for a truly cross-cultural dialogue in the process of the performance to create an interesting and beautiful conversation that the audience can fully enjoy and be part of.

STRAWSON: The performance I am working on right now deliberately fuses topeng with a Western fairy tale. I am showing that the form is useful and transportable. I am also hoping to pay homage to John Emigh, the man who is responsible for making topeng more widely known within Euro-American academic circles. In the mid-1980s he did a version of Little Red Riding Hood that put topeng "on the map" in some ways, and now, a generation later, I am retelling the same story, but from an eco-feminist perspective. So, despite my own dedicated training in Bali, the piece is inspired by an already altered version of topeng [that is, Emigh's Little Red Riding Shawl; see Emigh (1996: 261-267), which details the various versions and developments of this piece]. This mutation interests me because it explores a different, intercultural journey. Although I am not convinced that topeng travels well, there are two ways in which I feel that the form can really benefit one's performance practice. I find that daily training can inspire psychophysical responses and promotes a certain "mindfulness" in one's attitude to performance. This can be achieved both with and without the masks-each method leading to different, but still useful, results. Second, I feel that the principles and structures of topeng and the masks themselves can inspire new directions for contemporary devised material. 
COLDIRON: When performing with Ni Made Pujawati, we did a pretty standard topeng story with a standard structure. The story is based on the legend of the fourteenth-century king known as Bedahuluinterestingly, this is the story that inspired another of John Emigh's topeng adaptations, The Pig-Headed King. ${ }^{19}$ We took the Bedahulu story from de Zoete and Spies's Dance and Drama in Bali:

Tapa-Oeloeng went one day on a pilgrimage to Penoelisan with his patih, Pasoeng Grigis. And while he sat in meditation, his head mounted up to Svarga [heaven], leaving his body behind. Now the head stayed away so long that Pasoeng Grigis became anxious. And while he stood there in his perplexity a man came by carrying a pig. Suddenly Pasoeng Grigis had an idea; he bought the pig for fifty kepings [cents] and cut off its head and stuck it on the raja's body. When Tapaoeloeng woke from his meditation and saw his face mirrored in Lake Batoer, he wept bitterly and refused to return to Bedoeloe. He would rather, he said, live like a wild pig in the forest. At last Pasoeng Grigis persuaded him, promising to build him a pavilion so high that no one should be able to see him from below. So the king always sat up aloft in his high pavilion, and if anyone looked up he shot an arrow and killed him (de Zoete and Spies 1938: 295-296 ["oe" used here is "u" in the newer spelling]). ${ }^{20}$

In due course, the great general of the Majapahit Empire, Gajah Mada, comes to the court of Bedahulu and contrives to see the face of the king. The king is consumed by anger and bursts into flame, and his powerful meditation means that his soul goes straight to heaven (moksha). Bali becomes part of the Majapahit Empire, and everyone lives happily ever after. It is an interesting story for nonBalinese audiences because in the course of the story one can impart a lot about Balinese religion and culture and make use of several comic bondres masks. Naturally we include a "tourist" character (me, in my best/worst Texas accent) who wants to take photos of the king's procession, and there is the rather foolish and stupid pig farmer who takes the money he has made on the sale of his pig's head and gets dancing lessons from "Susi"-a canny young woman who also invites members of the audience to dance with her, and then the Penasar comes on to bring the story to a close. Our performances are for family audiences and in a purely secular context, so we don't have any reason to use the Sidha Karya mask, which normally is the last mask in sacred or ceremonial performances in Bali. ${ }^{21}$ All of the characters are male, except Susi, but since our audiences aren't generally aware that topeng is traditionally performed by men, they don't seem to question our gender. Since I'm taller, I play the strong roles of topeng Keras and Penasar, 
and Puja plays Dalem, the refined king, and Susi, but she also plays Bedahulu when he appears with his pig's head and some of the male bondres. Because of the circumstances of performance, I really don't feel that our being women and playing these male roles is in any way remarkable or inappropriate. Finding a sufficiently powerful and convincing voice for the Penasar is challenging, however, and something I continue to work on.

Since our residencies are about introducing people to Balinese topeng, I feel it is appropriate that we do a very traditional story in a traditional way, rather than trying to create some kind of East-West fusion piece. Nonetheless, I rather regret that I have not had much occasion to go outside the basic nature of topeng performance to explore other possibilities with the masks. I wish I were still carving because it would be interesting to do some more creative, original work in the way that Tiffany and Carmencita have done. That said, I did work with Agung Ngurah to develop masks for Thiasos Theatre Company's production of Euripides's Hippolytos, which brought together West Javanese jaipongan dance style with Balinese masks in an adaptation of an ancient Greek tragedy. ${ }^{22}$

I was pleased when one of my students recently came up with her own topeng Tua Wanita (old woman mask) piece that she performed for a summer festival. Ni Made Pujawati and I have discussed doing a topeng version of Jokasta [from the Oedipus myth] that would mix topeng and arja with wayang (shadow puppetry), but so far it is still in the planning stages.

\section{Q: How do you contribute to the performance practice in Bali?}

PALERMO: My being in Bali learning, performing, and interviewing is already an interaction that transforms the course of performance practice. For my teacher I will always be a little pupil to take care of, or the person who can organize funding for a project.

STRAWSON: I'm not sure. Sometimes, especially in the early days, I felt I was just an accessory to my teacher, and at other times my presence, as a woman and as a foreigner, seemed confusing to others. This double othering is an interesting perspective to review any notion of periphery and center. Sometimes I felt very self-conscious of the elevated position of the performer; being given drinks, snacks, food, sitting on an elevated platform, and being treated as part of this high-caste entourage of which I was a part.

As I got used to performing and could begin to stand my ground and not embarrass myself or my teacher, I realized that for many Balinese people, especially the younger generation, the interest that foreigners take in Balinese culture can validate its special 
appeal in the hearts and minds of local people. It makes them feel proud, possibly even culturally superior, and this regenerates interest. I remember, when I was on the Bali Arts and Culture Scholarship program, performing in the Taman Budaya (Cultural Centre) in Jogjakarta. We were expecting a very small audience, and then two thousand university students showed up and there was a television audience of six million! The purpose of all this carefully managed attention was to say: "Look, here are a bunch of Westerners performing your dances! It must be cool if they do it!"

GOLDIRON: I don't think I personally have any effect on Balinese performance, because I don't spend enough time in Bali. However, I'd like to think my "scholarly" work, giving papers at conferences on traditional and contemporary Balinese and intercultural performances, and engaging in dialogue with other performers and people at ISI in Denpasar, might have some knock-on effects down the line. I am doing more to promote Bali and Balinese performance as a teacher and performer in the UK and elsewhere. I hope to raise consciousness about the artists, genres, and culture and also send people to Bali to study and find out for themselves.

\section{Q: What do you transmit when you teach outside Bali?}

PALERMO: I try to focus on principles through which it is possible to make the mask alive. I mix Balinese technique with commedia dell'arte technique to put together an approach that is crossculturally comprehensible. I always underline that I'm an Italian who currently lives in Australia who has spent years in Indonesia. Wherever I teach, I'm the "Other" talking about the "Other."

STRAWSON: I always feel a certain duty to be an ambassador of culture for Bali. I am not sure what I transmit, but people have remarked on my obvious passion as I can talk about it and I can tell funny stories until the end of time! When teaching topeng it is always difficult to teach in depth (in the time available). Often one has to focus on breadth, and this can feel like a compromise, but perhaps the performer feels something of what the mask can do or what the performing body can experience. This is incredibly satisfying to share.

COLDIRON: I try to transmit a love for the masks, for the form, for the deep spirit of the idea of bringing the mask to life and a respect and reverence for all of it. In practical terms I teach people how to stand and walk and understand the meaning of the movements so they can fill them with conscious motivation. Likewise I hope to transmit the meaning and character of the masks, how viscerally different it is to be topeng Keras as opposed to topeng Dalem or 
topeng Tua, and then the more subtle differences between different versions of the "Strong Prime Minister." However, a lot of the time I find myself just telling my students to keep their elbows up. That sounds so reductive, but in the end it is mastery of technique that allows one to be creative and make art.

\section{Q: Why do you do what you are doing?}

PALERMO: I do it to gain that amazing pleasure of being one with the mask, the music, and the audience.

STRAWSON: It has to do with love. If there was no love, I would have stopped years ago for practical reasons, but I feel a very strong calling to be in Bali, to carve, and to dance in these masks. My interest is, I confess, not simply about performance. I am not a religious person, but I do feel some kind of spiritual connection with Bali and these masks, and it feels like a pilgrimage that is necessary. If I don't go, after a while, I ache to be in Bali. I feel a longing that becomes hard to bear. I feel a need to hear the gamelan, put on a mask, and dance in a ceremony. A Balinese person might say those like us, who give up our comfortable lives here and leave our families to go and live among the Balinese, that perhaps we have lived in Bali before, maybe somehow our souls are Balinese. I just know that I simply feel content in the world of topeng, and there is little else that makes me feel as happy or as fulfilled, even if there is no audience.

COLDIRON: Yes, well, I agree with all of this. I feel it is now deeply a part of me and isn't just a passing phase or a transitory interest. The wonderful thing about topeng is that you can never be too old for it. You might not have the physical power to be a very energetic topeng Keras at eighty, but I can imagine being able to have a powerful enough stillness to make it work. I love teaching because I want to spread this passion and enthusiasm.

Q: Why do you think there are still so few women performing topeng in Bali?

PALERMO: Time is a big factor, but there are other reasons; in interviews I have done recently, many women expressed the need for a clear leadership to make a successful performance group. If we consider how Topeng Shakti started, we see the vital importance of Ni Desak Nyoman Suarti in the initial phase, and then Cristina Formaggia - they had the vision to put the group together and create work. Motivation is also important, so the prospect of having international tours stimulates a lot of interest in performers. However, a group whose work does not appeal to local taste or fashion is not sustainable. 
There is another factor, too, which is the lack of funding for producing new performances. Performers and musicians need funds for transportation and food, and without this it is very hard to gather enough people to work on a new production. An additional factor in maintaining a company's motivation is to have some well-established competition that will make the group strive for greater achievement. In the case of topeng, although it can have a lot of comic elements, topeng is just not funny enough. Contemporary audiences in Bali, just like audiences elsewhere in the world, really want to laugh, and so far the all-female groups haven't really reached that level of "comicality" to achieve real success. Finally, there is the matter of fashion. So, when the first all-woman topeng group started, they were popular and several groups sprouted up, but the novelty wore off. This is typical of many forms of Balinese performances, so we should not be too much surprised by the apparent death of the all-female topeng phenomenon.

In general I would say that strong female figures such as Cristina Formaggia, Ni Desak Suarti, and Rucina Ballinger, who are willing to apply for funding and use their connections to organize international tours and promote their groups, are the means by which women's performance will thrive. Unfortunately, when the agenda of these powerful artistic entrepreneurs changes, there will be a shift in interest for the groups they lead. This trend could be seen in the 1970s and 1980s and is still a factor today. I believe the best contemporary example of an artist who has the leadership and networking skills to make a success is Emiko Susilo, who leads the dynamic Balinese music and dance group Çudamani, based in the village of Pengosekan, and the well-known Bay Area-based gamelan group Sekar Jaya. She is successful not only because of her artistic and organizational talent, but also for her family links. The daughter of distinguished artist-scholars Hardjo Susilo [professor emeritus of Univeristy of Hawaii] and Judy Mitoma [professor emeritus of UCLA], she is married to composer and musician Dewa Berata, with whom she leads Cudamani. Her journey has not been without difficulties, but she has been able to create a sustainable group because they focus on training children and young people. Her own children are an example of her success as a role model since her daughter is an excellent drum and gender player, which are roles traditionally belonging to men, and she is a wonderful dancer. However, it may take many more generations to see widespread, practical involvement of women in topeng. As a genre, topeng has had to roll with the times; change is inevitable, and the incorporation of new ideas is one reason why the form still exists today with 
such vigor and popularity. I am excited to see what new contributions women will make for the future of topeng in Bali and beyond.

STRAWSON: This is an excellent question! I think the notion of women being able to take traditionally male roles in performing arts is slowly becoming something that Balinese women, and men, are willing to accept. Nonetheless, it is an act of bravery to get involved. I agree with Carmencita, in that "fashion" is involved and, at the heart of this, it is to do with women and girls not wanting to look ugly or seem too masculine. Kecantikaan, the aesthetic of beauty, is so deeply rooted in the Balinese psyche. The culture does not really allow for a range of different female images, as may be seen elsewhere-in Bali, fashion dictates that beauty is feminine, long hair, lots of makeup, and "sexy." The alternative image of a woman, in popular theatre and on television, is an aged and overweight clown figure-there is little in between. Despite women taking on more responsibility with the household economy, gender roles are still pretty prescriptive when it comes to adat (customary behavior) and conventional social norms. Balinese women who enter the male-dominated topeng world are likely to have their motives questioned-the assumption might be that they want to do it so they can have an affair. I had the opportunity to work with Rucina Ballinger's performance troupe Grup Gedebong Goyang during their tour of Suud Merjor-joran (which translates as "Stop Fighting") in 2012. They are not a topeng troupe, but a group of expatriate Western women who perform comedy sketches in a typical bondres (clown) style. Frequently young girls and women in the audience would be invited to join the group on stage as "guests." They would always politely refuse, because they did not want to appear to be too bold, too experimental, too different. We must bear in mind that culturally in Bali, individuality is not encouraged. ${ }^{23}$ Now there are, of course, many Balinese women with strong, assertive personalities who are willing to take risks: Cok Sawitri, a journalist, poet, playwright, novelist, and activist who is one of the most innovative and controversial figures on the Balinese arts scene, is just such an example. However, it may take many more generations for widespread, practical involvement of women in topeng. As a genre, topeng has had to roll with the times. Change is inevitable, and the incorporation of new ideas is one reason why the form still exists today with such vigor and popularity. I am excited to see what new contributions women will make to the future of topeng in Bali and beyond.

COLDIRON: In looking at our own motivation and experiences in performing topeng, there are some interesting coincidences. We share 
many of the same interests-in masks and masked performance, in the process of embodying the mask-and we have had similar experiences in our training. I would venture to say that we have similar personalities in that we are assertive risk takers, but these qualities make us different from the norm in our own cultures and very different from the norm for women in Balinese culture. The advantage that we have is that in Bali we are "other," so that the social rules that inhibit our Balinese "sisters" do not apply to us. The bravest of our Balinese colleagues, like Cok Sawitri, Desak Suarti, and Ni Made Pujawati, are all women who have experienced life outside Bali and moved beyond conventional expectations. As contact with the world outside increases through mass media and social networking, through contact with visitors and opportunities for foreign study, it may be that the forces that currently inhibit Balinese women from asserting themselves as topeng performers may no longer hold sway. However, it is important that we continue to do what we are doing, if for nothing else than to demonstrate that it can be done, and to explore and expand this dynamic, creative performing art.

\section{NOTES}

1. Of course the situation was not quite this simple. There had been a great deal of intercultural flow in both directions, and in Indonesia female participation in traditionally male arts activities such as playing gamelan was encouraged by New Order policies and increasing tourism; see Palermo (2009).

2. The institution has been known variously as ASTI (Akademi Seni Tari Indonesia; Academy of Indonesian Dance), STSI (Sekola Tinggi Seni Indonesia; Indonesian Arts College), and ISI (Institut Seni Indonesia; Indonesian Arts Institute), and as of 2014 was in the process of becoming ISBI (Institut Seni dan Budaya Indonesia; Indonesian Institute of Arts and Culture).

3 . Women are perceived as more vulnerable to powers of "black magic" or negative spiritual energy, since menstrual blood is believed to attract demonic forces. Former president Sukarno's daughter Sukmawati is said to have studied for the role in the 1970s, but she did not perform it. Ballinger performed the role with the all-female group Luh Luwih, based in Pengosekan, south of Ubud. The group first performed the exorcistic drama Calonarang at the Pura Dalem in Pengosekan in 2003 with American dancer and musician Emiko Susilo in the role of Rangda. Ballinger took the role in 2004 at a performance at the Pura Taman Pule in Mas. Ballinger was praised for her boldness in taking on the role, but did not perform in a sacred mask. (See Diamond 2008: 252-253.)

4. Ni Desak Suarti is best known as a jewelry designer of international 
standing, but she is also highly regarded as a traditionally trained dancer and is an important supporter and funder of the arts in Bali.

5. The title plays on the Indian and Balinese interpretations of the Sanskrit term referring to both the female counterpart to Hindu deities and supernatural spiritual power.

6. Kecak is a dance-drama form invented in the 1930s through a collaboration between the European artist and polymath Walter Spies and Balinese performers from south Bali. Its most distinctive feature is the rhythmic vocal chant, derived from the trance ritual performed by prepubescent girls of sanghyang dedari (literally, "heavenly goddesses") that accompanies the drama.

7. These teachers are all part of the department of puppetry (pedalangan). Whereas Sweka, from Karangasam Province in northeastern Bali, focuses mainly on traditional forms in his work, Suteja is passionate about finding a language for contemporary dance in Indonesia, influenced by the time he spent pursuing his master's degree in Yogyakarta.

8. Traditional training in Bali follows an informal guru-sisya (teacherstudent) type of system in which a student is "apprenticed" to a particular teacher and does not follow or take lessons with others.

9. Whereas in Indian Hinduism, Pasupati refers to the god Shiva as Lord of the animals, in Balinese Hinduism, the term refers to a ceremony of purification in which the protective powers of Siwa (India, Shiva) are invoked to impart spiritual energy to an individual or object.

10. The mask of the strong prime minister, a powerful warrior whose movement is very energetic, but contained; it is the first mask to appear in a topeng performance.

11. The prime minister of Dalem Bedahulu, the king with the "different head" ( $b e d a=$ different; $h u l u=$ head), a magically powerful Balinese king whose head, when he meditated, would leave his body and float to heaven. The story is outlined later in the article.

12. An arrogant and aggressive character that Slattum describes as "the archetypal town drunk" (1992: 42). The mask has heavy features, a broad nose, and a wide mouth with thick lips.

13. A description of this state, as noted in Palermo's PhD thesis (2007: 8) can also be found in Etienne Decroux (1963) and Dario Fo (1997 [1987]: 41-42).

14. Putu Wijaya, in his remarks at the opening of the 2011 Bali Arts Festival, which had "desa, kala, patra" as its theme, had this to say: "For the Balinese desa (space) is essential to indicate origins, links and directions. By tracing their space the Balinese discover their linkage to their homes, origins braya-pisaga-semeton (society, neighbors, and family) and even with their guests. The space is also linked to kala (time). Night and day, morning and afternoon, today and tomorrow can change, take form, and make those links to time perfect. Finally, patra (identity) also means situation and condition, indicating that space and time can be harmonized with what is taking place" (Ellingson 2012).

15. Bondres are the comic masks, usually half-masks, that function as storytellers in traditional topeng, but bondres has also become an entertainment genre in its own right that features only the comic masks. 
16. I Wayan Dibia, a noted scholar and performer who is an authority on a wide range of Balinese performance genres, particularly arja, kecak, and barong performance. He co-authored, with Rucina Ballinger, Balinese Dance, Drama and Music: A Guide to Performing Arts of Bali (2004).

17. Ni Nyoman Candri, a noted arja performer, was central to Cristina Formaggia's Topeng Shakti group.

18. "Rejang Dewa" (Offering to the Gods) and "Panyembrama" (Welcome) are adapted from traditional temple dances to the gods to serve as more generic "welcome dances" appropriate for tourist performance. "Rejang Dewa" is particularly interesting because it was an adaptation of a sacred dance made for secular use, which has now returned to the temples as part of religious ceremonial. "Teruna Jaya" (Victorious Youth) is an archetypal dance of the virtuosic North Balinese kebyar style and is considered bebancihanbetween genders-and so may be danced by men or women.

19. This piece was composed in collaboration with I Wayan Suweca in the 1970s, in the aftermath of the Watergate scandal, and became a "universal parable of political overreaching and tyranny." The pig-headed head of state in Emigh's initial version represented Richard Nixon (see Emigh 1996: 259).

20. This version is slightly different from the version that Emigh based his piece on. In the de Zoete and Spies (1938) version, Tapa-Oeloeng is a good king and only becomes a dangerous tyrant when he gets his "different head."

21. For a detailed discussion of the story and significance of this mask, see Kodi et al. (2005: 171-198).

22. Further discussion of this production can be found in Coldiron (2007).

23. Strawson gave further details: "Daring to be different takes a lot of risk. Another example of this is something I discovered in leading drama workshops with Balinese children, playing the simple game Grandma's Footsteps [called Red Light, Green Light in the United States]. The game requires that somebody wants to win and that somebody will push themselves forward, faster and more strategically than the other players. The game would take ages to play, or completely fail, because nobody, male or female, would want to assert his or her difference. Nobody would want to win. It was very endearing because it reminded me of how, from such a young age, even children do everything together communally in Bali."

\section{REFERENCES}

Bandem, I Made, and Frederik deBoer. 1995.

Balinese Dance in Transition: Kaja and Kelod. 2nd ed. Kuala Lumpur: Oxford University Press.

Coldiron, Margaret. 2004.

Trance and Transformation of the Actor in Japanese Nō and Balinese Dance Drama. Lampeter, UK: Edwin Mellen Press.

2007.

"Sendratari Yunani: Negotiating the Languages of Intercultural Perfor- 
mance in an Indonesian-Style Greek Tragedy." Indonesia and the Malay World 35, no. 101: 129-140.

de Zoete, Beryl, and Walter Spies. 1938.

Dance and Drama in Bali. London: Faber and Faber.

Decroux, Etienne. 1963.

Paroles sur la mime (Talking about Mime). Paris: Gallimard.

Diamond, Catherine. 2008.

"Fire in the Banana's Belly: Bali’s Female Performers Essay the Masculine Arts." Asian Theatre Journal 25, no. 2: 231-271.

Dibia, I Wayan, and Rucina Ballinger. 2004.

Balinese Dance, Drama, and Music: A Guide to the Performing Arts of Bali. Singapore: Periplus Editions.

Ellingson, Mari. 2012.

"Bali: A Truly Memorable Cultural Evening." My Magic Moments, 23 June. https://islandmeri.wordpress.com/tag/desa-kala-patra, accessed 19 January 2015.

Emigh, John. 1996.

Masked Performance: The Play of Self and Other in Ritual and Theatre. Philadelphia: University of Pennsylvania Press.

Fo, Dario. 1997 [1987].

Manuale Minimo dell'attore (A Brief Manual for Actors). Torino: Einaudi.

Gold, Lisa. 2005.

Music in Bali: Experiencing Music, Expressing Culture. Oxford: Oxford University Press.

Goodlander, Jennifer. 2012.

"Gender, Power and Puppets: Two Early Women Dalangs in Bali." Asian Theatre Journal 29, no. 1: 54-77.

Goris, Roelof. 1954.

Praçasti Bali (Balinese Inscriptions), 2 vols. Bandung: Masa Baru.

Herbst, Edward. 1998.

Voices in Bali: Energies and Perceptions in Vocal Music and Dance Theatre. Hanover, NH: Wesleyan University Press and University Press of New England.

Kodi, I Ketut, I Gusti Putu Sudarta, I Nyoman Sedana, and I Made Sidia. 2005. “Topeng Sidha Karya: A Balinese Mask Dance." Introduced by Kathy Foley. Asian Theatre Journal 22, no. 2: 171-198.

Palermo, Carmencita. 2007.

"Towards the Embodiment of the Mask. Balinese Topeng in Contemporary Practice." PhD thesis, University of Tasmania.

2009.

“Anak mula keto 'It Was Always Thus': Women Making Progress, Encountering Limits in Characterising the Masks in Balinese Masked Dance-Drama." Intersections: Gender and Sexuality in Asia and the Pacific 19 (February). http://intersections.anu.edu.au/issue19/palermo.htm, accessed 11 September 2013. 
2012.

"Respirando para dentro da máscara - o corpo toma forma no teatrodança balinês topeng: uma experiência de aprendizado" (Breathing into the Mask. The Body Takes Form in Balinese Dance-drama Topeng: A Learning Experience). In [AA.VV.] Teatro de Máscaras (Theatre of Masks), ed. Valmor Beltrame and Milton de Andrade. Brazil: Universitadade Do Estato De Santa Catarina - UDESC. https://docs.google .com/a/ucsc.edu/file/d/0BziGRGosU2OiYm1VNFlTYXZ0d2c/edit, accessed 29 May 2015.

Slattum, Judy. 1992.

Masks of Bali: Spirits of an Ancient Drama. San Francisco: Chronicle Books.

Susilo, Emiko Saraswati. 2003.

"Gamelan Wanita: A Study of Women's Gamelan in Bali." Southeast Asia Paper 43. Honolulu: Center for Southeast Asian Studies, School for Hawaiian, Asian and Pacific Studies, University of Hawai'i at Mānoa.

Wikan, Unni. 1990.

Managing Turbulent Hearts, A Balinese Formula for Living. Chicago: University of Chicago Press. 